Effets de l'huile de soja sur les lipoprotéines plasmatiques et le risque cardiovasculaire chez I'homme et la femme

\title{
Effects of soybean oil on plasma lipoproteins and cardiovascular risk in men and women
}

Oléagineux, Corps Gras, Lipides. Volume 9, Numéro 2, 96-9, Mars - Juin 2002, La filière

Auteur(s) : Jean-Michel LECERF, Bénédicte BORGIES, Institut Pasteur de Lille, Service de nutrition, BP 245, 59019 Lille Cedex, France.

Author(s) : Jean-Michel LECERF, Bénédicte BORGIES

Résumé : Indépendamment des phytostérols et des autres composants de la graine (protéines, isoflavones), I'huile de soja présente plusieurs autres atouts qui lui confèrent des effets préventifs vis-à-vis du risque cardiovasculaire et des maladies coronariennes. Elle contient $61 \%$ d'acides gras polyinsaturés et seulement $15 \%$ de saturés, et ne comporte pas d'acide gras trans : sa consommation peut donc permettre une réduction du cholestérol total et du cholestérol LDL. C'est également une huile riche en vitamine $E$, et particulièrement en gamma tocophérol dont l'activité antioxydante connaît aujourd'hui un regain d'intérêt. Enfin, sa teneur élevée en acide alpha-linolénique est compatible avec des propriétés antithrombotique et antiarrythmique, mais la faible biodisponibilité de cet acide gras dans l'huile de soja en limite peut-être les effets.

Summary : Apart from the phytosterols and the other components of the bean (proteins, isoflavones) soybean oil presents several characteristics that give it a preventing effect on cardiovascular risk and coronary heart disease. With $61 \%$ of polyunsaturated fatty acids and only $15 \%$ of saturated fatty acids, without transfatty acids, soybean oil diets may decrease total and LDL cholesterol. Soybean oil is also rich in vitamin E, especially in gamma tocopherol whose antioxydant activity deserves more attention today. Finally, its large content in alpha linolenic acid may induce an antithrombotic and antiarrythmic effect, but this effect is perhaps restricted by the poor bioavailability of this fatty acid in soybean oil.

Mots-clés : huile de soja, prévention des maladies cardiovasculaires, cholestérol, lipoprotéines plasmatiques, acides gras.

Keywords : soybean oil, cardiovascular disease prevention, cholesterol, plasma lipoproteins, fatty acids.

\section{ARTICLE}

The lipid fraction of soybean accounts for $20 \%$ of the bean and can explain some of the effects of soybean on coronary heart diseases, beside those of the other components. The fatty acids composition of the soybean oil (Table 1) is as follows: saturated fatty acids (SFA), only 15\%; monounsaturated fatty acids (MUFA), $24 \%$; and polyunsaturated fatty acids (PUFA), $61 \%$ with $7.2 \%$ of 
alpha linolenic acid (ALA) which is one of the two essential fatty acids. With rapeseed oil, walnut oil, linseed oil (not allowed for human nutrition in France) and wheat germ oil, soybean oil is one of the four or five high alpha linolenic acid oils. Since it is a high PUFA oil, it also contains a large amount of vitamin $\mathrm{E}(124 \mathrm{mg} / 100 \mathrm{~g})$ : it is the highest vitamin $\mathrm{E}$ oil after corn oil, but the largest part of vitamin $\mathrm{E}$ is supplied by gamma tocopherol whose antioxidant activity deserves more attention today [1].

Plasma, lipids and lipoproteins

First, fatty acids have an effect on plasma lipids and lipoproteins. It is well known that the replacement of SFAs by PUFAs (for $5 \%$ of energy intake) decreases total and LDL cholesterol (respectively by 0.52 and $0.36 \mathrm{mmol} / \mathrm{l}$ ). So, the lipid profile becomes less atherogenic [2]. The comparison of oils rich in mono- and polyunsaturated fats shows the same decrease of LDL cholesterol, but a higher decrease in triglycerides with PUFAs [3]. The effects of PUFAs on HDL cholesterol are less obvious. A high PUFAs intake (more than $10 \%$ of total energy intake) or a high $\mathrm{P} / \mathrm{S}$ (PUFA/SFA) ratio is associated with a lower level of HDL cholesterol than in the case of a high MUFA intake [4-6], but some authors do not confirm this point [7]. A high PUFA intake decreases the level of LDL cholesterol more than a high MUFA intake, so the ratio LDL C/HDL C may not change significantly $[8,9]$. Furthermore, the biological meaning of a low level of HDL cholesterol and of a decrease of HDL cholesterol through diet is not the same [10].

Metabolic and clinical studies with soybean oil

Here, we have eliminated the studies about hydrogenated soybean oil because their fatty acids content is quite different, with a large amount of trans fatty acids and a reduction of the natural cis polyunsaturated fatty acids.

On fasting lipids and lipoproteins

Many studies are coming from Asian countries comparing soybean oil and other widely used edible oils in these countries.

* Comparison with palm olein

Palm oil is rich in palmitic acid $(16: 0,38.2 \%)$ and in oleic acid $(18: 1,43.2 \%)$. There is no difference in total cholesterol, HDL cholesterol, LDL cholesterol in two studies [11, 12], and only a higher decrease of apo B and apo A1 with soybean oil [11].

* Comparison with coconut fat

Coconut fat is rich in medium chain triglycerides, in lauric acid (C12:0, 45.8\%) and myristic acid (14:0, $18.4 \%$ ) which are saturated fatty acids. The $\mathrm{P} / \mathrm{S}$ ratio in soybean oil diet was 4.0 against 0.25 in coconut fat diet. The first diet leads to a decrease of total (-21\%), LDL (-23\%), HDL cholesterol (-15\%) and of triglycerides $(-25 \%)$ while there was no change in the second [13].

* Comparison with various high monounsaturated oils

Three oils (olive oil, liquid lard, rice bran oil) in a high-fat diet (40\%) were compared to the soybean 
oil. Soybean oil has the largest effect on lowering LDL cholesterol, but it has also a reducing effect on HDL cholesterol since olive oil diet does not change LDL C and increases HDL C [14].

* Comparison with alpha linolenic, linoleic or oleic acid-rich oils

Four low-fat (26\%) experimental diets (one with soybean oil) were compared to a diet with a twofold SFA content, in normolipidemic men. There was no difference between the four experimental diets (rich in alpha linolenic, linoleic or oleic acid) with a mean decrease of $22 \%$ for LDL cholesterol, $41 \%$ for VLDL cholesterol and 19\% for apoprotein B [15].

* Comparison with dietary hydrogenated fats and with butter

Six diets ( $30 \%$ total fat) with the same amount of SFAs (except butter with a greater amount of SFAs) and the same amount of MUFAs but a higher amount of trans fatty acids (TFAs) for the hydrogenated fats (except butter whose natural trans fatty acids have not the same amount, origin and effect) were tested in moderately hypercholesterolemic men and women. The soybean oil diet with the lowest TFA content had the largest effect for lowering total cholesterol, LDL cholesterol and the total cholesterol/HDL cholesterol ratio [16], when compared to the high trans fatty acids diets obtained from hydrogenated fats and compared to the butter.

In postprandial state

De Bruin et al. have examined the postprandial effect of soybean and olive oils emulsions in order to know their metabolism.

With an oral vitamin A load [17] they have shown a lower retinyl palmitate chylomicrons, apo B48 in chylomicrons remnants and a lower HDL cholesterol in postprandial state after soybean oil. So there is a slower removal of olive oil correlated with a higher hepatic lipase activity while the decrease of HDL cholesterol is inversely correlated with hepatic lipase. So the competition between olive oil chylomicrons remnants and HDL for hepatic lipase may explain the lack of postprandial decrease of HDL cholesterol.

After intravenously administrated olive and soybean oils emulsions, they have shown also a faster removal of soybean emulsion inversely correlated with the initial triglycerides level [18].

\section{Mechanisms}

On HDL

Sola et al. have shown that the HDL lipoproteins from soybean oil were less fluid particles than HDL lipoproteins from olive oil. This is due to the difference in the composition of HDL in phospholipid fatty acids and may explain a higher efflux with olive oil [19].

\section{On LDL}

The fractional synthesis rate of free cholesterol and absolute synthesis rate of free cholesterol were measured and calculated for five diets (with $30 \%$ total fat). One of them was a soybean oil diet and was compared to a high-fat diet (39\%) [8]. The lowest LDL cholesterol was observed with soybean oil but was associated with a high fractional and absolute synthesis of free cholesterol, as compared to 
the other diets with a larger trans fatty acid content. So, with soybean oil diet, the decrease of LDL cholesterol is due to an increase of LDL clearance, and then to the improvement of the catabolic pathway.

Lipoprotein oxidation

PUFA-enriched diets are able to increase the LDL susceptibility to oxidation, whereas SFA and MUFA fatty acids are fairly resistant to oxidation. But LDL oxidation in the sub-endothelial space also depends on the LDL vitamin E content [20]. Therefore, soybean oil is a rich vitamin E oil, especially in gamma tocopherol (Table 2) whose antioxidant activity is well established [1]. So, if the diet also contains a high percentage of MUFAs, soybean oil does not increase LDL oxidation.

Platelet agregation and hemostatic factors

It is well known that n-3 fatty acids, particularly the eicosapentaenoic acid (EPA), play an important role in the prevention of coronary artery diseases. Their potential benefits come from their antithrombotic action, particularly through the inhibition of thromboxane A2 synthesis, the prostaglandin that causes platelet aggregation and vasoconstriction [21].

Now the purpose is to establish whether alpha linolenic acid (ALA), the essential fatty acid at the head of the $n-3$ serie, has the same effect.

Increasing dietary ALA raises EPA phospholipid concentration [22, 23]. ALA-rich diet decreases platelet aggregation either by modulating the effect of arachidonic acid or through desaturation and elongation to EPA. This could be impair-ed in case of DELTA- 6 desaturase alteration, as in diabetes mellitus. This may also occur when there is an excess of linoleic acid intake with a high linoleic acid/alpha linolenic acid ratio which may inhibit the conversion of ALAs to EPAs n-3 PUFAs, but soybean oil has a good ratio of 7.5. ALAs and EPAs have nearly the same effects on hemostatic factors, particularly on platelet aggregation and on thrombosis [24]. n-3 fatty acids have other effects such as inhibiting both cellular growth factors and the migration of monocytes, promoting the synthesis of beneficial nitric oxide in the endothelium, inhibiting the synthesis of anti-inflammatory cytokines (interleukin 1-b and tumor-necrosis-factor). Finally, n-3 fatty acids, ALAs and EPAs have an antiarrythmic effect which can prevent sudden death risk in acute myocardial infarction [25]. This ALA effect depends on its bioavailability conversion to EPA and does not seem to be a direct effect [26]. But the biodisponibility of fatty acids depends on their position on the glycerol, the best one being on the Sn-2. In soybean oil, there is only $27 \%$ alpha linolenic acid on the Sn-2, since $66 \%$ of alpha linolenic acid in rapeseed oil is on the $\mathrm{Sn}-2$.

Preventing effect of ALAs on cardiovascular risk and coronary heart diseases

Cardiovascular risk

Three prospective studies have shown that ALA dietary intake is inversely correlated with the cardiovascular risk: MRFIT (-37\%) [27], Nurse's Health Study (-45\%) [28], Physician's Health Study (59\%) [29]. Two case control studies have also observed an inverse relation between ALA serum concentration with stroke [29], and of ALA in adipose tissue with the risk of myocardial infarction [30]. But in the Euramic Study [30], the p value for trend was not significant after adjustment. 
Cardiovascular disease prevention

Few dietary intervention trials were conducted.

The Oslo Study is a primary prevention trial with a slight increase of PUFAs (soybean oil) and a decrease of SFAs: after 5 years, there was a fall myocardial infarction and sudden death (-47\%) [31].

There are three secondary prevention trials: the first (that of the London MRC) [32], a soybean diet, has shown a decrease of $18 \%$ in coronary artery disease events but soybean oil was given late after myocardial infarction. A few years later, the Oslo Diet Heart Study, with the same dietary intervention as in the Oslo Study, has shown a fall of $44 \%$ in fatal myocardial infarction [7]. More recently, the Lyon Diet Heart Study has shown a dramatic fall of more than $70 \%$ in all end points with a Mediterranean diet containing a high ALA intake with a high ALA and MUFA margarine [33]. In that study, the cardioprotective effect was quickly obtained, probably because of the antithrombotic and antiarrythmic effect of the ALA [33]. But these results cannot be extrapolated to a soybean-rich diet because in the Lyon Diet Heart Study the fats used came from rapeseed oil.

\section{CONCLUSION}

Soybean fatty acids may have a protective effect for cardiovascular diseases (Figure 1), independently of the others components of soybean oil such as phytosterols, and of the other components of the bean (proteins, isoflavones). Although the high PUFA content may lead to an enhanced lipoprotein oxidation effect, which is cancelled by the high vitamin E content of the soybean oil, and to a lower HDL cholesterol, the low SFA associated with a high PUFA content of the soybean oil without trans fatty acid (in non hydrogenated oils) may decrease LDL cholesterol in a positive way. Therefore, a high ALA diet is able to have an antithrombotic and antiarrythmic effect which explains its rapid protective effect, but the poor bioavailability of ALA in soybean oil leads to further studies to prove its own benefit (Figure 1).

\section{REFERENCES}

1. JIANG Q, CHRISTEN S, SHIGENAGA MK, AMES BN (2001). gamma tocopherol, the major form of vitamin $\mathrm{E}$ in the US diet deserves more attention. Am J Clin Nutr, 74: 714-22.

2. CLARKE R, FROST C, COLLINS R, APPLEBY P, PETO R (1997). Dietary lipids and blood cholesterol: quantitative meta analysis of metabolic ward studies. Br Med J, 314: 112-17.

3. GARDNER CD, KRAEMER HC (1995). Monounsaturated versus polyunsaturated dietary fat and serum lipids. A meta analysis. Arterioscler Thromb Vasc Biol, 15: 1917-27.

4. JACKSON RL, KASHYA PML, BARNHARD RL, ALLEN C, HOGG E, GLUECK CJ (1984). Influence of polyunsaturated and saturated fats on plasma lipids and lipoprotein in man. Am J Clin Nutr, 39: 58997.

5. SCHAEFER EJ, LEVY RI, ERNST ND, VAN SANT FD, BREWER HB (1981). The effect of low cholesterol, high polyunsaturated fat and low fat diets on plasma lipid and lipoprotein cholesterol levels in normal and hypercholesterolemic subjects. Am J Clin Nutr, 34: 1758-63.

6. SHEPHERD J, PACKARD CJ, PATSCH JR, GOTTO AM, TAUNTON OD (1978). Effects of 
polyunsaturated and saturated fat on the properties of high-density lipoproteins and the metabolism of apolipoprotein A1. J Clin Invest, 61: 1582-92.

7. IACONO JM, DOUGHERTY RM (1991). Lack of effect of linoleic acid on the high-density lipoprotein cholesterol fraction of plasma lipoproteins. Am J Clin Nutr, 53: 660-4.

8. MATTHAN NR, AUSMAN LM, LICHTENSTEIN AH (2000). Hydrogenated fat consumption affects cholesterol synthesis in moderately hypercholesterolemic women. J Lip Res, 41: 834-9.

9. ASCHERIO A, RIMM EB, GIOVANNUCCI EL, SPIEGELMAN D, STAMPFER M, WILLETT WC (1996).

Dietary fat and risk of coronary heart disease in men: cohort follow-up study in the United States. $\mathrm{Br}$ Med J, 313: 84-90.

10. ASZTALO SB, LEFEVRE M, WONG L, et al. (2000). Differential response to low-fat diet between low and normal HDL cholesterol subjects. J Lip Res, 41: 321-8.

11. MARZUKI A, ARSHAD F, RAZAK TA, JAARIN K (1991). Influence of dietary fat on plasma lipid profiles of malaysian adolescents. Am J Clin Nutr, 53 (Suppl.): 1010S-14S.

12. ZHANG J, PING W, CHUNRONG W, SCHOU CX, KEYON G (1997). Non-hypercholesterolemic effects of a palm oil diet in Chinese adults. J Nutr, 127 (Suppl.): 509S-13S.

13. MENDIS S, KUMARASUNDERAM R (1990). The effect of daily consumption of coconut fat and lipoproteins of young normolipidaemic men. Br J Nutr, 63: 547-52.

14. CHEN PR, TSAI CE (1995). Various high monounsaturated edible oils might affect plasma lipids differently in man. Nutr Res, 15: 615-21.

15. CHAN JK, BRUCE VM, MCDONALD BE (1991). Dietary alpha linolenic acid is as effective as oleic acid and linoleic acid in lowering blood cholesterol in normolipidemic men. Am J Clin Nutr, 53: 12304.

16. LICHTENSTEIN AH, AUSMAN LH, JALBERT SM, SCHAEFER EJ (1999). Effects of different forms of dietary hydrogenated fats on serum lipoprotein cholesterol levels. N Engl J Med, 340: 1933-40.

17. DE BRUIN TWA, BROUWER CB, VAN LINDE-SIBENIUSTRIP M, JANSEN H, ERKELENS DW (1993). Different post prandial metabolism of olive oil and soybean oil: a possible mechanism of the high density lipoprotein conserving effect of olive oil. Am J Clin Nutr, 58: 477-83.

18. BROUWER CB, de BRUIN TWA, JANSEN H, ERKELENS DW (1993). Different clearance of intravenously administrated olive oil and soybean oil emulsions: role of hepatic lipase. Am J Clin Nutr, 57: 533-9.

19. SOLA R, BAUDET MF, MOTTA C, MAILLE M, BUISNIER C, JACOTOT B (1990). Effects of dietary fats on fluidity of human high-density lipoprotein: influence of the overall composition and phospholipid fatty acids. Bioch Bioph Act, 1043: 43-51. 
20. TSIMIKAS S, REAVEN PD (1998). The role of dietary fatty acids in lipoprotein oxidation. Curr Opin Lipidol, 9: 301-7.

21. LECERF JM (2000). Acides gras essentiels. Encycl Méd Chir. Paris : Elservier, EndocrinologieNutrition, 10-542-F10; 9 p.

22. ALLMAN-FARINELLI MA, HALL D, KINGHAM K, PANG D, PETOXZ P, FAVALORO E (1999). Comparison of the effects of two low-fat diets with different alpha-linolenic: linoleic acid ratios on coagulation and fibrinolysis. Arterosclerosis, 142: 159-68.

23. MANTZIORIS E, JAMES M, GIBSON RF, CLELAND LG (1995). Differences exist in the relationships between dietary linoleic and alpha-linolenic acid and their respective long chain metabolites. $\mathrm{Am} J$ Clin Nutr, 61: 320-4.

24. FREESE R, MUTANEN M (1997). alpha-linolenic acid and marine long chain n-3 fatty acids differ only slightly in their effects on hemostatic factors in healthy subjects. Am J Clin Nutr, 66: 591-8.

25. KANG JX, LEAF A (2000). Prevention of fatal cardiac arrythmias by polyunsaturated fatty acids. Am J Clin Nutr, 71 (Suppl.): 202S-7S.

26. CHRISTENSEN JH, CHRISTENSEN MS, TOFT E, DYERBERG J, SCHMIDT EB (2000). alpha-linolenic acid and heart rate variability. Nutr Metab Cardiovasc Dis, 10: 57- 61.

27. DOLECEK JA, GRANDITS G (1991). Dietary polyunsaturated fatty acids and mortality in the multiple risk factor intervention trial. In: SIMOPOULOS AP, KIFER RR, MARTIN RE, BARLOW SM, eds. Health effects of ôméga3 polyunsaturated fatty acids in seafoods. World Rev Nutr Diet. Basel, Karger, 66: 2056.

28. HU FB, STAMPFER MJ, MANSON JE, et al. (1999). Dietary intake of alpha linolenic acid and risk of fatal ischemic heart disease among women. Am J Clin Nutr, 69: 890-7.

29. SIMON JA, FONG J, BERNERT JJ, BROWNER WS (1995). Serum fatty acids and the risk of stroke. Stroke, 26: 778-82.

30. GUALLAR E, ARO A, JIMENEZ FJ, et al. (1999). Omega-3 fatty acids in adipose tissue and risk of myocardial infarction. Arterioscler Thromb Vasc Biol, 19: III-8.

31. HJERMANN I, HOLME I, VELBE-BYRE K, LEREN P (1981). Effect of diet and smoking intervention on the incidence of coronary heart disease. Lancet, 2: 1303-12.

32. RESEARCH COMMITTEE TO THE MEDICAL RESEARCH COUNCIL (1968). Controlled trial of soybean oil in myocardial infarction. Lancet, 2: 693-700.

33. DE LORGERIL M, SALEN P, MARTIN JL, MONTAUD I, DELAYE J, MAMELLE N (1999). Mediterranean diet, traditional risk factors, and the rate of cardiovascular complications after myocardial infarction. Final report of the Lyon Diet Heart Study. Circulation, 99: 779-85. 
Illustrations

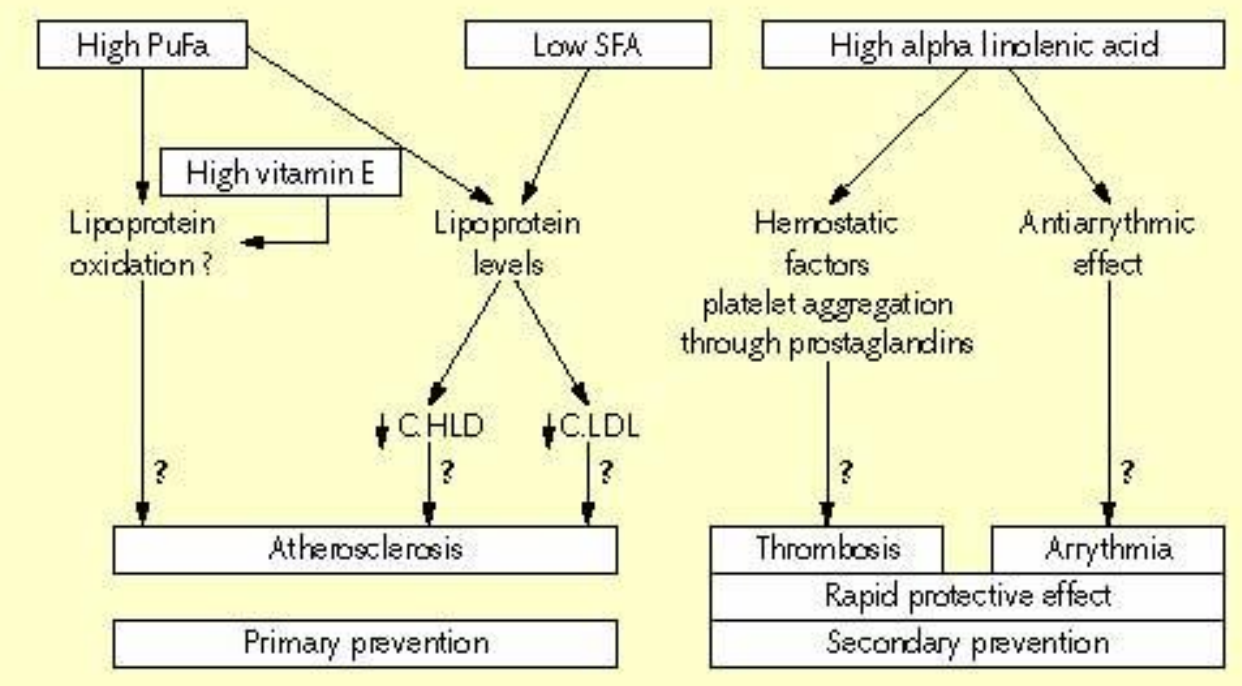

Figure 1. The mechanism of the cardioprotective effect of soybean oil.

Table 1. Composition of soybean and soybean oil in lipid and fatty acids.

\begin{tabular}{|c|c|c|}
\hline & Soybean & Soybean oil \\
\hline Lipid & 20\% on dry weig ht & $100 \%$ \\
\hline Fatty acids & & \\
SFA & & $15.1 \%$ \\
$16: 0$ & & $10.9 \%$ \\
$18: 0$ & & $4.0 \%$ \\
\hline MUFA & & $24.5 \%$ \\
$18: 1 \mathrm{n}-9$ & & $24.2 \%$ \\
\hline PUFA & & $60.8 \%$ \\
$18: 2 n-6$ & & $54.1 \%$ \\
$18: 3 n-3$ & & $7.2 \%$ \\
\hline P/S & & $4.0 \%$ \\
n-6/n-3 & & $7.1 \%$ \\
\hline
\end{tabular}

Table 2. Cortent of tocopher ok (vitamin $\theta$ ) in oils.

\begin{tabular}{|l|c|c|c|c|c|c}
\hline & $\begin{array}{c}\text { Soybean } \\
\text { oil }\end{array}$ & $\begin{array}{c}\text { Sunflower } \\
\text { oil }\end{array}$ & $\begin{array}{c}\text { Rapeseed } \\
\text { oil }\end{array}$ & $\begin{array}{c}\text { Corn } \\
\text { oil }\end{array}$ & $\begin{array}{c}\text { Olive } \\
\text { oil }\end{array}$ & $\begin{array}{c}\text { Peanut } \\
\text { oil }\end{array}$ \\
\hline ytocopherol & 11 & 69 & 26 & 20 & 8 & 18 \\
ytocopherol & 3 & 3 & - & 1 & 2 & 10 \\
ytocopherol & 74 & - & 36 & 121 & 2 & 22 \\
ytocopherol & 36 & - & 1 & 4 & - & - \\
Total ytocopherol & 124 & 72 & 63 & 146 & 12 & 50 \\
\hline
\end{tabular}

